\title{
Universities learning to play the market
}

The inability of the British government to match the qualifications of would-be university students to vacancies in science subjects was inevitable given government policies.

THE British government is nothing if not inconsistent. Dedicated as it has been for more than a decade to the principle that market forces will solve most social problems, it is nevertheless "disappointed" at the continuing decline (by a quarter in the past four years) of the numbers of young people leaving school with qualifications of the kind expected by science and engineering departments at British universities. That at least is what Baroness Blatch, the government's spokesman on education in the House of Lords, said last week about this year's crop of statistics of the numbers taking what are called A-level examinations in mathematics and science subjects. But she should not even be surprised. Her government's success in making careers in science and technology less attractive has been amply recorded in the years since 1979. And the screws are still turning; the prospect that basic research will in future be more tightly harnessed to industrial needs will discourage even those who might have been willing to suffer financial indignity for the sake of the traditional intellectual freedom of research. Lady Blatch can be "disappointed" only if she supposes that young people do not read the newspapers.

Of course, poor salaries (especially for graduate students) are only part of the explanation for the continuing unwillingness of young people to compete for places in science and engineering in higher education. The shortage of talented science teachers in schools is another, and it is too soon to know whether the government's present policy of letting secondary schools manage their own budgets if they choose will persuade some of them that paying science teachers more would be prudent. It is just as likely that school governors will argue that because the 'demand' in schools for A-level science is falling, they had better divert resources in other directions. Is not that the logic of the market?

Among the other partial explanations of the decline of science numbers is an archaic feature of the British educational system that Lady Blatch described last week as the "cornerstone" of her government's plan to promote "higher standards of achievement among young people". The reference is to the system of A-level examinations that has become the de facto entrance examination into higher education. And nowhere can it be denied that the system is a remarkable venture in cultivated precocity. Young people leaving British secondary schools with decent A-level grades probably know as much about their chosen subjects of study as do undergraduates elsewhere after their first year in higher education. What suffers is general education, illustrated by the notorious inability of British science school-leavers to speak any language but English (and, sometimes, not even that).

This state of affairs will not be remedied by the government, wedded as it is to the belief that skewed A-level attainment is its proudest achievement. Is there a chance that some among the universities (of which Britain now has many more, of great diversity) will have the wit to find a way out? After all, the ingredients of a better system are all in place. For one thing, the A-level pattern has recently been made less rigid by allowing students to follow broader courses (but very few choose to do so for fear of not commending themselves to their chosen universities). For another, the universities are themselves being forced towards charging fees for tuition by the government's attempt to rig the educational market in favour of science, implied in its reduction of the annual per capita payment to universities in respect of students in other fields. Canny universities will quickly tumble to the conclusion that they will be better off financially if they can persuade students in the arts and humanities to switch to science. It will be a short step from there to the conclusion that they might just as well short-circuit the A-level system altogether, choosing students by other criteria. And if that is the likely outcome, why not anticipate it? That is what the logic of the market commands.

\section{Babbitt on a roll}

Bruce Babbitt, has had a greater effect on the environment in six months than his predecessors had in years.

IN the US hierarchy of government posts, the secretaryship of the Department of the Interior has never reached the pinnacle. In fact, the names of most interior secretaries are forgotten the day after they are sworn in. Not so Bruce Babbitt, a man with a clear (and sensible) vision of the environment as a complex, live phenomenon and a man who has the president's ear.

Within weeks of taking office, Babbitt took steps to end an endless stalemate between environmentalists who wanted to protect every living red cockaded woodpecker and lumberers who wanted to cut down trees where the endangered birds live. Babbitt forged an agreement that permits lumbering provided companies preserve at least 10 acres of 